\title{
NILAI KECERNAAN IN VITRO BAHAN ORGANIK (KcBO) \\ DAN BAHAN KERING (KcBK) RUMPUT GAJAH \\ (Pennisetum purpureum Schumach \& Thonn) DENGAN PEMUPUKAN ORGANIK DAN ANORGANIK SERTA INOKULASI MIKROORGANISME EFEKTIF (EM4)
}

\author{
Teguh Wibowo $^{1,2}$, D.R.Lukiwati ${ }^{2}$ dan Sumarsono ${ }^{2}$ \\ ${ }^{1}$ Balai Besar Pelatihan Peternakan Batu, Kementerian Pertanian \\ Jl. Songgoriti No. 24 Batu 65301 - Indonesia \\ ${ }^{2}$ Fakultas Peternakan dan Pertanian, Universitas Diponegoro \\ Kampus Tembalang, Semarang 50274 - Indonesia \\ Email: marsono_53@yahoo.co.id
}

\begin{abstract}
ABSTRAK
Penelitian ini bertujuan untuk mengetahui nilai kecernaan invitro bahan organik dan bahan kering dari rumput gajah(Pennisetum purpureum Scumach \& Thon) yang dipupuk dengan pupuk anorganik (urea $=\mathrm{P} 1$ ) dan pupuk organik (pupuk kandang/pukan $=\mathrm{P} 2$ dan bahan organik kaya sumber nutrisi/bokashi $=\mathrm{P} 3$ )dikombinasi dengan inokulasi mikroorganisme efektif EM4 (E). Penelitian ini menggunakan rancangan acak lengkap petak terpisah dengan 3 kali ulangan. Petak utama berupa 8 kombinasi perlakuan sedangkan anak petak berupa defoliasi ke-1, 2 dan 3. Delapan kombinasi perlakuan tersebut yaitu: E0P0 (tanpa EM4, tanpa pupuk); E1P0 (EM4, tanpa pupuk); E0P1 (tanpa EM4, urea); E1P1 (EM4, urea); E0P2 (tanpa EM4, pukan); E1P2 (EM4, pukan); E0P3 (tanpa EM4, bokashi); dan E1P3 (EM4, bokashi). Pengaruh interaksi perlakuan pemupukan dan defoliasi berpengaruh nyata $(\mathrm{P}<0,05)$ pada kecernaan bahan organik $(\mathrm{BO})$ dan kecernaan BK sepanjang periode defoliasi. Pemupukan rumput gajah menggunakan pukan, bokashi atau urea (tanpa atau dengan inokulasi EM4) tidak mempengaruhi kecernaan BO dan kecernaan BK rumput gajah.
\end{abstract}

Kata Kunci: rumput gajah(Pennisetum purpureum Scumach \& Thon), nilai KcBO dan KcBK rumput gajah secara in vitro, defoliasi rumput gajah, pupuk kandang, bokashi, urea, EM4

\section{PENDAHULUAN}

Faktor utama yang berpengaruh terhadap pertumbuhan tanaman pakan adalah: tanah, air, udara dan sinar matahari (Sutanto, 2002). Tanah berperan dalam penyediaan unsur hara, air berperan sebagai pelarut dan transportasi unsur hara, sedangkan sinar matahari menyediakan energy yang penting untuk proses fotosintesis. Sinar matahari bersaa-sama dengan $\mathrm{CO}_{2}, \mathrm{H}_{2} \mathrm{O}$ dan unsur hara melalui proses fotosintesis akan membentuk zat metabolit yang sebagaian disimpan sebagai cadangan makanan bagi dan sebagian lagi digunakan sebagai penyusun jaringan struktur yang penting untuk mencegah penyakit (Lakitan, 2007).

Kesuburan tanah adalah keadaan tanah yang memiliki kemampuan untuk 
memberi nutrisi bagi tanaman (Marsono dan Sigit, 2002). Kesuburan tanaman berkaitan erat dengan sifat fisik, kimia dan biologis tanah. Sifat fisik tanah dapat diperbaiki dengan cara pengolahan tanah, sifat kimia tanah dapat diperbaiki dengan pemberian pupuk buatan sedangkan sifat biologis dapat diperbaiki dengan penambahan pupuk organik atau inokulasi mikroorganisme tertentu (Wididana etal. 1996). Upaya peningkatan produksi tanaman pakan selama ini cenderung menggunakan pupuk buatan. Kondisi ini disebabkan pupuk buatan dapat terurai dengan cepat, sehingga tanaman mudah menyerapnya. Namun demikian penggunaan pupuk buatan dengan dosis tinggi dan terus menerus dapat menimbulkan : (1) Keseimbangan unsur hara dalam tanah terganggu, menimbulkan polusi air, tanah, air irigasi maupun udara dan (3) Terganggunya pertumbuhan jasad renik karena sifat tanah berubah (Marsono dan Sigit, 2002).

Upaya untuk menghindari resiko yang ditimbulkan oleh penggunaan pupuk buatan yang berlebih adalah dengan penggunan pupuk organik maupun pupuk hayati (mikroorganisme efektif). Kotoran ternak memainkan peranan penting sebagai sumber pupuk organik. Dilaporkan bahwa ternak menghasilkan $19-40 \mathrm{Kg} / \mathrm{hr}$. Sekitar $3,5 \mathrm{~kg}$ bahan organik dikeluarkan oloeh sapi Jersey yang dikandangkan (Kerley et al, 1996 yang dikutip Sumarsono et al, 2005). Selain berfungsi menambahan unsur hara, pupuk organik juga dapat memperbaiki sifat fisik tanah dan biologis tanah (Sugito et al, 1996).Demikian juga dengan inokulasi mikroorganisme efektif yaitu mEM4 (Efektif Mikroorganisme-4) adalah suatu kultur campuran beberapa mikroorganisme yang dapat meningkatkan pertumbuhan tanaman melalui perbaikan kondisi tanah (Wididana et al. 1996).

Berdasarkan kerangka pikir tersebut, maka perlu penelitian tentang subsitusi pupuk buatan oleh pupuk organik dan inokulasi mikroorganisme dalam budidaya tanaman pakan ternak.Oleh karena itu, dilakukan penelitian ini yang bertujuan untuk mengetahui nilai kecernaan secara invitro bahan organik (KcBO) dan bahan kering (KcBK) rumput gajah(Pennisetum purpureum Scumach \& Thon) antara rumput gajahyang dibudidayakan dengan pemupukan menggunakan pupuk anorganik dan rumput gajah yang dibudidayakan dengan pemupukan menggunakan pupuk organik. Kedua jenis pupuk tersebut dikombinasi dengan inokulasi mikroorganisme efektif EM4.

\section{MATERI DAN METODE PENELITIAN}

\section{Materi Penelitian}

Bibit yang digunakan adalah stek rumput gajah yang berasal dari kebun rumput Balai Besar Pelatihan Peternakan (BBPP) Batu. Stek batang diambil dari batang yang sudah tua (menjelang tanaman berbunga). Ukuran stek yang digunakan masing-masing mengandung 2 buah buku (Rukmana, 2005).Pupuk yang digunakan pada penelitian adalah: pupuk kandang/pukan, urea (46\% N), bokashi,dan efektif mikroorganisme EM4.

Pot yang digunakan untuk penelitianterbuat dari plastik, dengan diameter $(\phi) \pm 1 \mathrm{~m}$ dan tinggi $1 \mathrm{~m}$. Tanah yang digunakan untuk media tanam dalam pot berasal dari lahan 'tidur' di BBPP Batu jenis inseptisol (Arifin,1999). Menurut USDA (1975) dalam Poerwowidodo(1992), jenis tanah tersebut dikelompokkan ke dalam ordo tanah pelikan, yang mempunyai bahan induk berasal dari batuan. Hasil 
analisis tanah didapatkan bahwa kandungan bahan organik sangat rendah, nitrogrn $(\mathrm{N})$ total rendah, kadar posfor $(\mathrm{P})$ tersedia sangat tinggi dan kalium (K) tersedia tergolong rendah.Cairan rumen sapi untuk percobaan kecernaan bahan kering dan bahan organik secara invitro diambil dari rumah potong hewan (RPH) Singosari, Kecamatan Singosari, Kabupaten Malang.

\section{Metode Penelitian}

\section{Rancangan Percobaan}

Penelitian dilakukan menggunakan rancangan acak lengkap (RAL) petak terbagi dengan 3 kali ulangan. Petak utama berupa 8 kombinasi perlakuan dan anak petak berupadefoliasi ke-1, 2 dan 3 .

Kombinasi perlakuan berupa kombinasi penggunaan pupuk anorganik yaitu urea $\left(\mathrm{P}_{1}\right)$ atau pupuk organik yaitu pukan $\left(\mathrm{P}_{2}\right)$ atau bokashi $\left(\mathrm{P}_{3}\right)$ dan inokulasi mikroorganisme efektifEM4 (E) pada budidaya rumput gajah. Kedelapan kombinasi perlakuan tersebut sebagai berikut :

$\mathrm{E} 0 \mathrm{P0}=$ tanpainokulasi $\mathrm{EM}_{4}$, tanpa

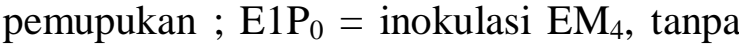

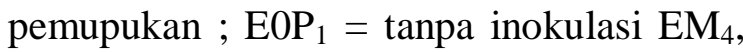
pemupukan urea $; \mathrm{E}_{1} \mathrm{P}_{1}=$ inokulasi $\mathrm{EM}_{4}$, pemupukan urea; $\mathrm{EOP}_{2}=$ tanpa inokulasi $\mathrm{EM}_{4}$,pemupukan pukan ; $\mathrm{E}_{1} \mathrm{P}_{2}=$ inokulasi $\mathrm{EM}_{4}$, Pemupukan pukan; $\mathrm{EOP}_{3}=$ tanpa inokulasi $\mathrm{EM}_{4}$, pemupukan bokhasi dan $\mathrm{E}_{1} \mathrm{P}_{3}=$ inokulasi $\mathrm{EM}_{4}$, pemupukan Bokhasi.

\section{Prosedur Penelitian}

Penelitian dilakukan di lahan praktek BBPP Batu, pada Bulan Juli 2005 Februari 2006. Penelitian dilakukan dalam beberapa tahap yaitu tahap 1adalah persiapan yang meliputi: analisa hara media tanam, pembuatan pupuk bokashi, analisa kandungan unsur $\mathrm{N}$ pupuk organik, analisa kandungan EM4, penyiapan lokasi (lahan), penyiapan bibit rumput gajah. Tahap 2 adalah penanaman dan aplikasi pupuk yang meliputi pupuk anorganik (urea) dan organik (pukan dan bokashi) yang diinokulasi mikroorganisme efektif (EM4). Tahap 3 adalah analisis data.

\section{Pelaksanaan Penelitian}

Pengukuran parameter/variabel penelitian dilakukan pada setiap kali defoliasi. Parameter/variabel penelitian meliputi:

1) Kecernaan secara Bahan Organik (KcBO) daun dan batang rumput gajah secara. invitro menurut Tilley dan Terry (1963).

2) Kecernaan Bahan Keering (KcBK) daun dan batang rumput gajah secara invitro menurut Tilley dan Terrry (1963).

\section{Analisis Data}

Data yang diperoleh dianalisis dengan menggunakan analisis ragam (ANOVA) menggunakan prosedur SPSS (versi 17.0). Perbedaan antar perlakuan diuji lanjut menggunakan Uji Jarak Berganda Duncan (UJGD) Level signifikan ditentukan pada $\mathrm{P}<0,05$.

\section{HASIL DAN PEMBAHASAN}

\section{Keadaan Lokasi Penelitian}

Lokasi penelitian di Kebun Praktek Balai Besar Pelatihan Peternakan Batu, pada ketinggian $900 \mathrm{~m}$ dari permukaan laut (dpl).Suhu udara $18-24^{\circ} \mathrm{Cdan}$ kelembaban nisbi60-70\%., dengan rata-rata jumlah harim hujan 20 dan curah hujan 208,17 $\mathrm{mm}$. Tanah pada lokasi penelitian termasuk jenis Inseptisol.Menurut USDA (1975) dalam Poerwowidodo (1992), jenis tanah tersebut dikelompokkan ke dalam ordo 
tanah Pelikan yang mempunyai bahan induk berasal dari batuan kapur lembut. Berdasarkaan hasil analisis tanah yang dilakukan, didapatkan bahwa kandungan bahan organik tergolong sangat rendah yaitu 1,64\%; nitrogen $(\mathrm{N})$ total rendah $(0,16 \%)$, kadar posfor $(\mathrm{P})$ tersedia sangat tinggi $(72,32 \mathrm{mg} / \mathrm{kg})$ dan kalium $(\mathrm{K})$ tersedia sangat rendah $(0,35 \mathrm{mg} / 100 \mathrm{~g}$

\section{Kecernaan Invitro Bahan Organik (KcBo) Rumput Gajah}

Kecernaan bahan organik diukur secara invitro seperti disajikan pada Tabel `1. Tidak terdapat pengaruh interaksi yang signifikan $\quad(\mathrm{P}>0,05) \quad$ untuk interaksi perlakuan pemupukan dan periode defoliasiterhadap kecernaan bahan organik rumput gajah. Begitu juga untuk pengaruh utama berupa perlakuan pemupukan dan berupa periode defoliasi juga menunjukkan tidak ada pengaruh yang signifikan $(\mathrm{P}>0,05)$ terhadap kecernaan bahan organik. Hal tersebut menunjukkan bahwa budidaya rumput gajah menggunakan berbagai pupuk organik atau urea tanpa atau menggunakan inokulasi EM4 tidak mempengaruhi kecernaan bahan organik rumput gajah.

Meskipun tidak signifikan, pemupukan rumput gajah dengan urea (tanpa atau dengan inokulasi EM4) menunjukkan KcBO tertinggi sepanjang periode defoliasi dibandingkan dengan berbagai pupuk organik. Hal ini karena sifat dari pupukorganik yang memerlukan waktu relatiflama untuk terurai jika dibandingkan dengan urea. Unsur hara urea hasil penguraiansegera bisa diabsorbsi sehingga dapat meningkatkan fotosintesis. Hasil fotosintesis yang diangkut dari daun ke titik tumbuh sangat menentukan pertumbuhan yang salah satunya ditunjukkan dalam bentuk produksi bahan kering dan bahan organik. Semakin tinggi laju fotosistesis, maka semakin tinggi produksi bahan kering dan bahan organik (Harjadi, 2002). Fathul dan Wajizah (2010) menyatakan bahwa bahan organik merupakan bagian dari bahan kering sehingga apabila bahan kering meningkat akan meningkatkan bahan organik betu pula sebaliknya. Hal ini didukung oleh Patty (1996) bahwa semakin tinggi bahan organik maka semakin tinggi $\mathrm{KcBO}$ ( kecernaan bahan organik).

Tabel 1 Kecernaan Bahan Organik (KcBO) secara In vitro pada Berbagai Periode Defoliasi dan Berbagai Jenis Pemupukan

\begin{tabular}{|c|c|c|c|c|}
\hline \multirow{2}{*}{ Perlakuan } & \multicolumn{4}{|c|}{ "Defoliasi Ke- } \\
\hline & 1 & 2 & 3 & Rerata \\
\hline & & $\%) \ldots \ldots$ & ......... & \\
\hline E0P0 & 58,96 & 59,75 & 58,47 & 59,06 \\
\hline E1P0 & 60,62 & 62,58 & 58,69 & 60,63 \\
\hline E0P1 & 59,18 & 63,68 & 59,13 & 60,15 \\
\hline E1P1 & 63,47 & 57,58 & 63,33 & 61,46 \\
\hline E0P2 & 58,74 & 58,90 & 57,60 & 58,92 \\
\hline E1P2 & 62,24 & 59,25 & 59,78 & 60,42 \\
\hline E0P3 & 60,46 & 58,84 & 60,49 & 59,93 \\
\hline E1P3 & 60,40 & 57,23 & 60,42 & 59,35 \\
\hline Rerata & 60,88 & 59,73 & 59,74 & \\
\hline SE & 0,69 & & & \\
\hline
\end{tabular}

Keterangan:

$\mathrm{SE}=$ Standar Eror

${ }^{\mathrm{a}-\mathrm{c}}$ Rerata pada baris yang sama dengan superskrip yang berbeda menunjukkan adanya perbedaan yang nyata $(\mathrm{P}<0,05)$ 
${ }^{\mathrm{p}-\mathrm{r}}$ Rerata pada kolom yang sama dengan superskrip yang berbeda menunjukkan adanya perbedaan yang nyata $(\mathrm{P}<0,05)$

A-I Rerata pada baris dan kolom yang sama dengan superskrip yang berbeda menunjukkan adanya perbedaan yang nyata $(\mathrm{P}<0,05)$

$\mathrm{SE}=$ Standar Eror

\section{Kecernaan In vitro Bahan Kering (KcBK)}

Data kecernaan invitro bahan kering diukur pada tiga kali defoliasi. Data tersaji pada Tabel 2. Tidak terdapatpengaruh interaksi yang signifikan $(\mathrm{P}>0,05)$ untuk interaksi perlakuan pemupukan dan periode defoliasiterhadap kecernaan bahan kering rumput gajah. Begitu juga untuk pengaruh utama berupa perlakuan pemupukan dan berupa periode defoliasi juga menunjukkan tidak ada pengaruh yang signifikan $(\mathrm{P}>0,05)$ terhadap kecernaan bahan kering. Hal tersebut menunjukkan bahwa budidaya rumput gajah menggunakan berbagai pupuk organik atau urea tanpa atau menggunakan inokulasi EM4 tidak mempengaruhi kecernaan bahan kering rumput gajah.

Tabel 2 Kecernaan Bahan Kering (KcBK)secara In vitro pada Berbagai Periode Defoliasi dan Berbagai Jenis Pemupukan

\begin{tabular}{|c|c|c|c|c|}
\hline \multirow{2}{*}{ Perlakuan } & \multicolumn{4}{|c|}{ Defoliasi Ke- } \\
\hline & 1 & 2 & 3 & Rerata \\
\hline & \multicolumn{3}{|c|}{ (\%) } & \\
\hline EOPO & 62,61 & 62,88 & 59,92 & 61,80 \\
\hline E1P0 & 63,59 & 61,28 & 60,95 & 62,94 \\
\hline E0P1 & 62,30 & 66,04 & 59,97 & 62,77 \\
\hline E1P1 & 66,14 & 61,53 & 64,13 & 63,93 \\
\hline E0P2 & 62,31 & 61,70 & 61,06 & 61,69 \\
\hline E1P2 & 65,54 & 59,31 & 62,18 & 62,34 \\
\hline E0P3 & 63,00 & 60,67 & 62,21 & 61,96 \\
\hline E1P3 & 63,55 & 56,32 & 60,08 & 59,98 \\
\hline \multicolumn{5}{|l|}{ Rerata } \\
\hline \multicolumn{5}{|l|}{ SE } \\
\hline \multicolumn{5}{|l|}{ Keterangan: } \\
\hline \multicolumn{5}{|c|}{$\begin{array}{l}\text { a-c Rerata pada baris yang sama dengan superskrip yang berbeda menunjukkan } \\
\text { adanya perbedaan yang nyata }(\mathrm{P}<0,05)\end{array}$} \\
\hline \multirow{2}{*}{\multicolumn{5}{|c|}{$\begin{array}{l}\mathrm{pr} \text { Rerata pada kolom yang sama dengan superskrip yang berbeda menunjukkan } \\
\text { adanya perbedaan yang nyata }(\mathrm{P}<0,05)\end{array}$}} \\
\hline & & & & \\
\hline \multirow{2}{*}{\multicolumn{5}{|c|}{$\begin{array}{l}\text { A-I Rerata pada baris dan kolom yang sama dengan superskrip yang berbeda } \\
\text { menunjukkan adanya perbedaan yang nyata }(\mathrm{P}<0,05)\end{array}$}} \\
\hline & & & & \\
\hline $\mathrm{SE}=\mathrm{S}$ & & & & \\
\hline
\end{tabular}

Meskipun tidak signifikan, nitrogen berperan penting dalam proses pemupukan rumput gajah dengan urea fotosintesis. Semakin tinggi laju (tanpa atau dengan inokulasi EM4) fotosistesis, maka semakin tinggi produksi menunjukkan KcBK tertinggi sepanjang bahan kering (Harjadi, 2002). Selanjutnya periode defoliasi dibandingkan dengan penelitian Patty (1996) menyatakan bahwa berbagai pupuk organik. Hal ini karena sifat semakin tinggi bahan kering maka semakin dari pupuk organik yang memerlukan tinggi KcBk, begitu pula sebaliknya. waktu penguraian yang relatif lama. Kondisi ini menunjukkan bahwa unsur hara 
SIMPULAN DAN SARAN

Pemupukan rumput gajah menggunakan pukan, bokashi atau urea (tanpa atau dengan inokulasi EM4) tidak mempengaruhi kecernaan BO dan kecernaan BK rumput gajah secara in vitro.

Disarankan perlunya dilakukan penelitian lebih lanjut tentang peranan pupuk organik dan EM4 terhadap nilai nutrisi rumput gajah pada defoliasi selanjutnya (ke-4, 5 dan seterusnya). Dengan demikian sehingga dapat diperoleh peran optimal pupuk organik dan inukolasi EM4.

\section{DAFTAR PUSTAKA}

Fathul, F dan S. Wajizah, 2010. Penambahan $\mathrm{Mn}$ dan $\mathrm{Cu}$ dalam ransum Terhadap Aktivitas Biofermentasi Rumen Domba secara In Vitro. Jurnal Ilmu Ternak dan Veteriner, 15 (1) : 9-15

Harjadi, S.S. 2002. Pengantar Agronomi. Gramedia Pustaka Utama, Jakarta

Lakitan, B. 2007. Dasar Dasar Fisiologi Tumbuhan. Raja Grafindo Persada, Jakarta.

Marsono dan P. Sigit. 2000. Pupuk Akar (Jenis dan Aplikasinya). Penebar Swadaya, Jakarta.

Patty,C.W. 1996. Pengaruh Aras Pemupukan Nitrogen Pada King Grass Terhadap Kecernaan Nutrien, Parameter Fermentasi Rumen, Sintesis N Mikroba dan Neraca N Pada Sapi Perah. Tesis Program Pasca Sarjana Universitas Gajah Mada. Yogyakarta.

Poerwowidodo, 1992. Telaah Kesuburan Tanah. Angkasa, Bandung.
Reksohadiprodjo, S., 1994. Produksi Tanaman Hijauan Makanan Ternak Tropik. BPFE. Yogyakarta.

Rukmana, R. 2005. Rumput Unggul Hijauan Makanan Ternak. Kanisius, Yogyakarta.

Sugito, Y., Y. Nur aini dan E. Nihayati. 1995. Sistem Pertanian Organik. Fakultas Pertanian Universitas Brawijaya, Malang.

Sumarsono, S. Anwar dan S. Budiyanto. 2005. Aplikasi Pupuk Organik Ternak pada Tanah Salin untuk Pengembangan Tanaman Rumput Pakan Poliploid. Laporan Penelitian Hibah Penelitian kompetensi A3. Jurusan Nutrisi dan Makanan Ternak Fakultas Peternakan Universitas Diponegoro, Semarang. Tilley,J.M. and R.A.Terry.1963. A TwoStage Technique For The In.Vitro Digestion Of Forage Crops.J.BrGrausl.SOC.18.

Tillman, A.D., H. Hartadi, S .Reksohadiprodjo,S. Prawirokusumo dan S. Lebdosoekojo.1998. Ilmu Makanan Ternak Dasar. Gajah Mada

Wididana,G.N., S.K. Riyanto, dan T.Higa, 1996. Teknologi dan Effective Microorganisms. Koperasi Karyawan Departemen Kehutanan, Jakarta.

Yuniati, E., 1999. Pengaruh Pemberian Kompos Azolla (Azolla mikrophylla) dan Mikroorganisme Efektif terhadap Kualitas dan Produksi Rumput Raja (Pennisetum Purpureum). Fakultas Peternakan. Universitas Brawijaya. Malang. (Tesis Magister Pertanian). 